\title{
Methanolic Crude Extract of Hagenia abyssinica Possesses Significant Antidiarrheal Effect: Evidence for In Vivo Antidiarrheal Activity
}

\author{
Zemene Demelash Kifle ${ }^{D},{ }^{1}$ Seyfe Asrade Atnafie ${ }^{(D},{ }^{1}$ Tesfaye Yimer Tadesse ${ }^{(D},{ }^{2}$ \\ Teshome Fentik Belachew, ${ }^{3}$ and Birhanu Berihun Kidanu ${ }^{4}$ \\ ${ }^{1}$ University of Gondar, College of Medicine and Health Sciences, School of Pharmacy, Department of Pharmacology, \\ Gondar, Ethiopia \\ ${ }^{2}$ Debretabor University, College of Health Science, Department of Pharmacy, Debre Tabor, Ethiopia \\ ${ }^{3}$ Department of Pharmacy, Debre Birhan Health Science College, Debre Birhan, Ethiopia \\ ${ }^{4}$ University of Gondar, College of Veterinary Medicine and Animal Sciences, Department of Veterinary Pharmacy, \\ Gondar, Ethiopia
}

Correspondence should be addressed to Zemene Demelash Kifle; ppharma737@gmail.com

Received 19 March 2021; Revised 8 May 2021; Accepted 10 May 2021; Published 17 May 2021

Academic Editor: Francesca Mancianti

Copyright ( $) 2021$ Zemene Demelash Kifle et al. This is an open access article distributed under the Creative Commons Attribution License, which permits unrestricted use, distribution, and reproduction in any medium, provided the original work is properly cited.

\begin{abstract}
Background. Hagenia abyssinica is one of the most commonly used medicinal plants for the treatment of diarrhea in Ethiopia. Therefore, this study aimed to evaluate the antidiarrheal effect of methanol crude extract of $H$. abyssinica leaves in mice. Methods. Acute toxicity testing was conducted using Organization for Economic Cooperation and Development guidelines. The antidiarrheal activity of the crude extract of $H$. abyssinica was investigated using three animal models such as small intestine transit, enteropooling, and castor oil-induced diarrhea models. The extract was administered at three different doses (100, 200, and $400 \mathrm{mg} / \mathrm{kg}$ ) to the test groups, while the positive control group received $3 \mathrm{mg} / \mathrm{kg}$ of loperamide and the negative control group received $10 \mathrm{ml} / \mathrm{kg}$ of vehicle (distilled water). Results. The crude extract of $H$. abyssinica did not exhibit death at the limit dose ( $2 \mathrm{~g} /$ $\mathrm{kg}$ ) throughout the observation period. In the castor oil-induced model, the crude extract at a dose of $200 \mathrm{and} 400 \mathrm{mg} / \mathrm{kg}$ exhibited a significant $(P<0.05)$ antimotility effect as compared to the negative control. The crude extract revealed a significant reduction in the volume and weight of intestinal contents at 200 and $400 \mathrm{mg} / \mathrm{kg}$ doses of the extract. Moreover, the highest antidiarrheal index (ADI) was obtained with the dose of $400 \mathrm{mg} / \mathrm{kg}$ of crude extract, which was comparable to the standard drug. Conclusion. The crude extract of Hagenia abyssinica possesses antidiarrheal activity and supports the traditional use of $H$. abyssinica for the management of diarrhea.
\end{abstract}

\section{Introduction}

According to the World Health Organization, diarrhea is the passage of three or more loose or liquid stools per day [1]. Although diarrhea is a preventable and treatable disease, it is the $2^{\text {nd }}$ leading cause of death in children under 5 years old [2]. Globally, there are nearly 1.7 billion cases of childhood diarrheal disease every year. Diarrhea is a leading cause of malnutrition in children under five years old and kills around 525, 000 children under five [1].
Diarrhea is the most common problem in low-income countries like Africa. In Africa, about $26 \%$ of incidents of diarrhea were reported [3]. Patients with mild diarrhea have a self-limited sickness necessitating no management. However, in severe diarrhea, risks like electrolyte imbalance and dehydration are common, predominantly in elderly, children, and infant patients. These patients require zinc supplements, antimicrobials, oral rehydration therapy, antisecretory agents, and antimotility agents [4]. 
The World Health Organization estimated that about $80 \%$ of the population in low-income countries depend on plant-based medicines [5]. Numerous herbal medicines that possess antidiarrheal effects are existing in the biosphere. The antidiarrheal effects of these herbal medicines have been accredited to the presence of phytoconstituents such as tannins, flavonoids, alkaloids, steroids, terpenoids, and saponins [6]. In the previous study, the crude leaf extract of $H$. abyssinica comprises phytoconstituents such as flavonoids, phenols, anthraquinones, triterpenoids, and saponins [7]. Similarly, the leaf solvent fractions of $H$. abyssinica contain secondary metabolites such as alkaloids, flavonoids, tannins, glycosides, phenols, anthraquinones, terpenoids, and saponins [8].

Scientific investigation for the search on novel antidiarrheal compounds from medicinal plants such as Caylusea abyssinica [9], Ixora coccinea [10], Ficus sycomorus [11], Vernonia amygdalina [12], Myrtus communis [13], and Justicia schimperiana [14] revealed promising findings. The medicinal plant $H$. abyssinica belongs to the genus Hagenia and the family Rosaceae [15]. The species occurs in Tanzania, Kenya, Uganda, Congo, Ethiopia, Malawi, Burundi, Rwanda, and Sudan [16]. The whole plant is traditionally used for the treatment of fever/cough, stomachache, livestock disease, and malaria treatment. The flower part of $H$. abyssinica is used for tapeworm, epilepsy, wound healing, evil eye, problems related to bile, and sexually transmitted diseases [17, 18]. The leaf of $H$. abyssinica has been used in the treatment of diarrhea in Ethiopian folk medicine $[17,19,20]$. Pharmacological investigation reports showed that the extract of $H$. abyssinica has a considerable antibacterial activity against the bacterial species (Staphylococcus aureus and Salmonella typhi) [21]. In the previous study, the leaf solvent fractions of $H$. abyssinica showed significant antidiarrheal activity in mice [8]. However, there is no previous study in the in vivo antidiarrheal effect of the leaf crude extract of $H$. abyssinica in Swiss albino mice. Thus, the present study aimed to investigate the in vivo antidiarrheal effect of the leaf crude extract in Swiss albino mice.

\section{Materials and Methods}

2.1. Drugs, Chemicals, and Instruments. Loperamide hydrochloride (Brawn Laboratories Ltd., India), activated charcoal (Acuro Organics Ltd., New Delhi), methanol (Blulux, India), castor oil (Amman Pharmaceutical Industries, Jordan), hot air oven (Medite Medizintechnik, Germany), vacuum freeze dryer (Labfreez Instruments Group Co., Ltd., Germany), digital thermometer (Infiniti Medlab Pvt., Ltd., India), and microhematocrit centrifuge (Medite Medizintechnik, Germany) were used in the study.

2.2. Plant Materials. The fresh leaves of $H$. abyssinica were collected in Kosoye, Ethiopia, on February 12, 2019, and wrapped with plastic sheets during transportation. The botanical identification and authentication of the plant material were performed by a botanist at the University of
Gondar, Ethiopia, with the voucher specimens' number $003 Z \mathrm{ZK} / 2019$.

2.3. Extraction. The collected plant leaves were shade-dried at room temperature. The powdered plant materials were weighed by sensitive digital weighing balance, and a total of $1050 \mathrm{~g}$ of powdered leaves were macerated with $80 \%$ methanol $(262.5 \mathrm{~g}$ in $1500 \mathrm{ml})$ in four Erlenmeyer flasks for $72 \mathrm{~h}$ at room temperature with occasional stirring and shaking, and then, the extracts were filtered by using Whatman filter paper No.1. The marc was remacerated two times with fresh solvent, each for $72 \mathrm{~h}$, and the filtrates obtained from the successive maceration were concentrated in a rotary evaporator (Hamato, Japan) under reduced pressure at $40^{\circ} \mathrm{C}$. The semidried residues were frozen in the refrigerator overnight and then dried using a lyophilizer (Labfreez, China) to completely remove the solvent residue. Then, the dried leaves' extract was kept separately in a desiccator until used for the experiment $[22,23]$.

\subsection{Experimental Animal Handling, Grouping, and Dosing.} Adult Swiss albino mice of either sex weighing between 25 and $30 \mathrm{~g}$ were purchased. The animals were housed in a standard polyethylene glycol cage, with the provision of a standard diet and water ad libitum. The animals were allowed for a one-week acclimatization period. These animals were kept under standard conditions of humidity, temperature, and $12 \mathrm{~h}$ light $/ 12 \mathrm{~h}$ dark cycle. During the experimental period, the animals were randomly assigned into five groups (negative control, three test groups, and positive control) comprising six animals per group. Group I (negative controls) were treated with vehicle (distilled water); group II, III, and IV were treated with 100, 200, and $400 \mathrm{mg} / \mathrm{kg}$ of the crude extract of $H$. abyssinica, respectively, while group $\mathrm{V}$ received loperamide $(3 \mathrm{mg} / \mathrm{kg})$ orally.

2.5. Acute Toxicity Testing. Acute toxicity testing was conducted using Organization for Economic Cooperation and Development guidelines. Accordingly, five female albino mice of 8-12 weeks were used. All mice were fasted (food but not water) overnight before and $2 \mathrm{~h}$ after the administration of the extract. The first animal was given a limit dose of $2 \mathrm{~g} /$ $\mathrm{kg}$, and then four other mice were sequentially treated based on the outcome of the first animal and observed for any signs of toxicity daily for 14 days such as loss of appetite, hair erection, lacrimation, tremors, convulsions, salivation, diarrhea, mortality, and other signs of toxicity [24].

2.6. Castor Oil-Induced Diarrhea Model. The method used was described by Kifle and Molla [8, 25], with a slight modification. Thirty Swiss albino mice of either sex were fasted for about $18 \mathrm{~h}$ and grouped randomly into 5 groups as mentioned above. After $1 \mathrm{~h}$ of treatment with the vehicle, 100,200 , and $400 \mathrm{mg} / \mathrm{kg}$ of the crude extract, and loperamide hydrochloride $(3 \mathrm{mg} / \mathrm{kg})$, diarrhea was induced by oral administration of $0.5 \mathrm{ml}$ of castor oil to each mouse. Then, the mice were placed individually into metabolic cages in 
which the floor is lined with transparent paper for the collection of fecal matters. The transparent paper altered every one hour for a total of four hours. The mice were observed for a period of four hours. The mice were removed from their cages, and the weight of feces was obtained by subtracting the weight of filter paper from the weight of feces and filter paper. The number of wet stools, the onset of diarrhea, the total number, and the total weight of fecal output were noted. The percentage of the weight of total fecal output and the percentage of diarrheal inhibition were determined by using the following formulas:

$$
\text { percentage inhibition }(\%)=\frac{\text { mean number of WFC }- \text { mean number of WFT } \times 100}{\text { mean number of WFC }},
$$

where WFC is the wet feces in the control group and WFT is the wet feces in the test group, and

$$
\text { percentage of fecal output }(\%)=\frac{\text { mean fecal weight of each treatment group } \times 100}{\text { mean fecal weight of control }} .
$$

2.7. Castor Oil-Induced Intestinal Transit Model. The test was done according to Molla and Kifle [8, 25], with a slight modification. Mice were fasted for $18 \mathrm{~h}$, but with free access to water. The mice were grouped into 5 groups and preserved as described above. After one hour of treatment, $0.5 \mathrm{ml}$ castor oil was given to each mouse. Then, $1 \mathrm{ml}$ of $5 \%$ activated charcoal was administered by oral route. The mice were then sacrificed by cervical dislocation $2 \mathrm{~h}$ after castor oil administration. The small intestine was dissected out from pylorus to caecum and placed lengthwise on white paper. The total length of the intestine and the distance traveled by the charcoal meal were then measured and expressed as a peristaltic index:

$$
\begin{aligned}
& \text { peristaltic index }(\mathrm{PI})=\frac{\text { distance travelled by charcoal meal } \times 100}{\text { whole length of small intestine }}, \\
& \text { percentage inhibition }=\frac{\text { PI of control group }- \text { PI of test group } \times 100}{\text { PI of control group }} .
\end{aligned}
$$

2.8. Castor Oil-Induced Enteropooling Model. The method used by Suliman et al. [26] was used to evaluate the activity of the crude extract on castor oil-induced intestinal fluid accumulation. The mice were assembled and treated in the same way as described above. One hour later, $0.5 \mathrm{ml}$ of castor oil was given to each mouse. One hour after the administration of castor oil, the mice were sacrificed by cervical dislocation and the small intestine of each mouse was weighed. Then, the intestinal content of all groups was transferred into a tube. After removal of the intestinal content, the intestine of each mouse was reweighed and the volume of each intestinal content was measured. Finally, the percent reductions in the volume and weight of intestinal content were determined using the following formulas:

$$
\% \text { reduction in weight of intestinal content }=\frac{\text { weight of intestinal content in } \mathrm{NC}-\text { weight of intestinal content in TG } \times 100}{\text { weight of intestinal content in the negative group }}
$$

where NC is the negative control group and TG is the treated group, and

$\%$ reduction in volume of intestinal content $=\frac{\text { volume of intestinal content in NC }- \text { volume of intestinal content in TG } \times 100}{\text { volume of intestinal content in the negative group }}$. 
2.9. In Vivo Antidiarrheal Index. The method used by Hussain et al. [27] was used to calculate the in vivo antidiarrheal index (ADI) for the test and control groups. The ADI was calculated using the following formula:

$$
\text { ADI in vivo }=\sqrt[3]{(\text { Dfreq } \times \text { Gmeq } \times \text { Pfreq })}
$$

where Gmeq is the gut meal travel reduction as \% of negative control, Pfreq is the reduction in the number of stools as \% of the negative control, and Dfreq is the delay in defecation time or diarrhea onset which is calculated as follows:

$$
\text { Dfreq }=\frac{\text { mean onset of diarrhea in the treated group }- \text { mean onset of diarrhea in the negative control } \times 100}{\text { mean onset of diarrhea in the negative control group }} .
$$

2.10. Statistical Analysis. The collected data were analyzed using the software Statistical Package for Social Sciences (SPSS), version 24. Thus, the results were expressed as mean \pm standard error of means (SEM). The significance of differences between groups was analyzed by using oneway ANOVA followed by post hoc Tukey's test. A $P$ value of less than 0.05 was considered statistically significant.

\section{Results}

3.1. The Percentage Yield of Extraction. The crude extract obtained at the end of the extraction process was $153 \mathrm{~g}$ (14.6\%).

3.2. Acute Toxicity Test. With the acute toxicity test at the limit test dose of $2 \mathrm{~g} / \mathrm{kg}$, neither mortality nor changes related to behavioral, autonomic, neurologic, and physical profiles were observed within the first $24 \mathrm{~h}$ and during the 14-day follow-up. The dose was considered as the maximum tolerated dose, and thus, $1 / 5^{\text {th }}, 1 / 10^{\text {th }}$, and $1 / 20^{\text {th }}$ doses of $2 \mathrm{~g} /$ $\mathrm{kg}$ were selected for the present study.

3.3. Effects of Crude Extract of $H$. abyssinica on Castor Oil-Induced Diarrheal Model. In the castor oil-induced diarrhea model, diarrhea was ostensible in all mice of the negative control group, for the next $4 \mathrm{~h}$. The percentage inhibition of defecation by the crude extract was $42.85 \%$, $55.71 \%$, and $73.85 \%$ at the doses of $100 \mathrm{mg} / \mathrm{kg}, 200 \mathrm{mg} / \mathrm{kg}$, and $400 \mathrm{mg} / \mathrm{kg}$, respectively. Similarly, this was noticeably $(87.5 \%)$ reduced by the oral administration of the standard drug (loperamide $3 \mathrm{mg} / \mathrm{kg}$ ). All tested doses of the crude extract of $H$. abyssinica significantly $(P<0.001)$ delayed the onset of diarrhea when compared to the negative control. Likewise, all tested doses $(100 \mathrm{mg} / \mathrm{kg}, 200 \mathrm{mg} / \mathrm{kg}$, and $400 \mathrm{mg} / \mathrm{kg})$ of the crude extract significantly $(P<0.05$, $P<0.01, P<0.001$, respectively) reduced the number of wet feces and the total number of feces when compared to the negative control (Table 1).

3.4. Effects of Crude Extract of H. abyssinica on Castor Oil-Induced Intestinal Transit in Mice. The crude extract of H. abyssinica at the middle $(200 \mathrm{mg} / \mathrm{kg})$ and higher $(400 \mathrm{mg} /$ $\mathrm{kg})$ doses significantly $(P<0.01, P<0.001$, respectively $)$ repressed propulsion of charcoal. However, the lower dose of the extract $(100 \mathrm{mg} / \mathrm{kg})$ lacks noticeable activity on the peristalsis of the intestine when compared to the negative control. As shown in Table 2, the percentage reduction of gastrointestinal transit of charcoal was $14.87 \%, 29.20 \%$, and $54.00 \%$ for the crude extract at doses of $100 \mathrm{mg} / \mathrm{kg}, 200 \mathrm{mg} /$ $\mathrm{kg}$, and $400 \mathrm{mg} / \mathrm{kg}$, respectively. Similarly, the standard drug (loperamide) reduced the small intestinal transit significantly $(P<0.001)$ with a percentage value of $67.1 \%$ (Table 2$)$.

3.5. Effects of Crude Extract of $H$. abyssinica on Castor Oil-Induced Enteropooling. In the intestinal fluid accumulation model, the crude extract of $H$. abyssinica exhibited a significant reduction in both the average volume and weight of intestinal contents at the middle $(200 \mathrm{mg} / \mathrm{kg})$ and higher $(400 \mathrm{mg} / \mathrm{kg}$ ) doses of the extract as compared to the negative control. The percentage inhibition of weight of intestinal contents was $25 \%(P<0.01)$ and $46 \%(P<0.001)$ at doses of $200 \mathrm{mg} / \mathrm{kg}$ and $400 \mathrm{mg} / \mathrm{kg}$, respectively, as compared to the negative control. Similarly, the percentage inhibition of volume of intestinal contents was $27.6 \%(P<0.01)$ and $45.0 \%$ $(P<0.001)$ at doses of $200 \mathrm{mg} / \mathrm{kg}$ and $400 \mathrm{mg} / \mathrm{kg}$, respectively, as compared to the negative control. Likewise, the percentage inhibition of volume and weight of intestinal contents by loperamide $3 \mathrm{mg} / \mathrm{kg}$ was $47.8 \% \quad(P<0.001)$ and $50.0 \%$ $(P<0.001)$, respectively, as compared to the negative control (Table 3).

3.6. Antidiarrheal Index. The in vivo ADI showed that the greatest ADI was achieved at the dose of $400 \mathrm{mg} / \mathrm{kg}$ of crude extract (81.24\%) among the three doses of crude extracts. ADI increased with a dose for hydromethanolic crude extract of $H$. abyssinica but lower than the ADI of loperamide (99.48\%). The crude extract of $H$. abyssinica displayed an ADI of $36.23 \%, 59.00 \%$, and $81.24 \%$ at doses of $100 \mathrm{mg} / \mathrm{kg}$, $200 \mathrm{mg} / \mathrm{kg}$, and $400 \mathrm{mg} / \mathrm{kg}$, respectively (Table 4 ).

\section{Discussion}

Plant-based medicines have been studied for the search of new antidiarrheal agents with advanced efficacy and safety. The activity of these medicinal plants on electrolyte secretion, water secretion, and GI transit was assessed by in vivo models [28]. Thus, the current study was aimed to evaluate the effectiveness and safety of $H$. abyssinica as an 
TABLE 1: Effects of crude extract of $H$. abyssinica on castor oil-induced diarrhea.

\begin{tabular}{lcccc}
\hline Group & Onset of diarrhea $(\mathrm{min})$ & Number of wet feces & Number of total feces & \% inhibition of defecation \\
\hline Control & $58.50 \pm 3.45$ & $7.00 \pm 0.73$ & $9.83 \pm 0.83$ & - \\
Crude $100 \mathrm{mg} / \mathrm{kg}$ & $102.16 \pm 7.79^{\mathrm{a} 3 \mathrm{~b} 1}$ & $4.00 \pm 0.44^{\mathrm{ab} 1}$ & $5.00 \pm 0.68^{\mathrm{a} 1 \mathrm{~b} 1}$ & 42.85 \\
Crude $200 \mathrm{mg} / \mathrm{kg}$ & $132.33 \pm 6.33^{\mathrm{a} 3}$ & $3.10 \pm 0.22^{\mathrm{a} 2 \mathrm{~b} 2}$ & $3.72 \pm 0.53^{\mathrm{a} 2}$ & 55.71 \\
Crude $400 \mathrm{mg} / \mathrm{kg}$ & $137.16 \pm 7.84^{\mathrm{a} 3}$ & $1.83 \pm 0.21^{\mathrm{a} 3}$ & $2.66 \pm 0.33^{\mathrm{a} 3}$ & 73.85 \\
Loperamide $3 \mathrm{mg} / \mathrm{kg}$ & $169.33 \pm 6.075^{\mathrm{a} 3}$ & $1 \pm 0.25^{\mathrm{a} 3}$ & $2.0 \pm 0.21^{\mathrm{a} 3}$ & 87.50 \\
\hline
\end{tabular}

Data are expressed as mean \pm SEM $(n=6)$. ${ }^{\mathrm{a} C o m p a r e d ~ t o ~ n e g a t i v e ~ c o n t r o l . ~}{ }^{\mathrm{b}}$ Compared to loperamide $3 \mathrm{mg} / \mathrm{kg} .{ }^{1} P<0.05,{ }^{2} P<0.01$, and ${ }^{3} P<0.001$. Negative controls received $10 \mathrm{ml} / \mathrm{kg}$ distilled water.

TABLE 2: Effects of crude extract of $H$. abyssinica on castor oil-induced gastrointestinal motility.

\begin{tabular}{|c|c|c|c|c|}
\hline Dose administered & Length of small intestine $(\mathrm{cm})$ & Distance moved by the charcoal meal $(\mathrm{cm})$ & Peristaltic index (\%) & $\%$ inhibition \\
\hline Control & $57.10 \pm 1.24$ & $49.50 \pm 1.43$ & $86.70 \pm 1.48$ & - \\
\hline $100 \mathrm{mg} / \mathrm{kg}$ & $58.60 \pm 0.95$ & $43.26 \pm 3.73^{\mathrm{b} 3}$ & $73.80 \pm 4.91^{\mathrm{b} 3}$ & 14.87 \\
\hline $200 \mathrm{mg} / \mathrm{kg}$ & $59.00 \pm 1.12$ & $36.20 \pm 1.45^{\mathrm{a} 2 \mathrm{~b} 3}$ & $61.35 \pm 2.88^{\mathrm{a} 2 \mathrm{~b} 3}$ & 29.20 \\
\hline $400 \mathrm{mg} / \mathrm{kg}$ & $57.16 \pm 0.93$ & $22.00 \pm 1.32^{\mathrm{a} 3}$ & $39.85 \pm 1.97^{\mathrm{a} 3}$ & 54.00 \\
\hline Loperamide $3 \mathrm{mg} / \mathrm{kg}$ & $55.5 \pm 1.51$ & $15.83 \pm 0.94^{\mathrm{a} 3}$ & $28.52 \pm 1.08^{\mathrm{a} 3}$ & 67.10 \\
\hline
\end{tabular}

Data are expressed as mean $\pm \operatorname{SEM}(n=6) .{ }^{\mathrm{a} C o m p a r e d ~ t o ~ n e g a t i v e ~ c o n t r o l . ~}{ }^{\mathrm{b}}$ Compared to loperamide $3 \mathrm{mg} / \mathrm{kg} .{ }^{1} P<0.05,{ }^{2} P<0.01$, and ${ }^{3} P<0.001$. Negative controls received $10 \mathrm{ml} / \mathrm{kg}$ distilled water.

TABLE 3: Effects of crude extract of $H$. abyssinica on castor oil-induced enteropooling

\begin{tabular}{lcccc}
\hline Dose administered & $\begin{array}{c}\text { Mean volume of small intestinal content } \\
(\mathrm{g})\end{array}$ & $\begin{array}{c}\text { \% inhibition } \\
\text { Control }\end{array}$ & $\begin{array}{c}\text { Mean weight of small intestinal content } \\
(\mathrm{ml})\end{array}$ & $\begin{array}{c}\text { \% inhibition } \\
100 \mathrm{mg} / \mathrm{kg}\end{array}$ \\
$0.69 \pm 0.09$ & - & $0.76 \pm 0.01$ & - \\
$200 \mathrm{mg} / \mathrm{kg}$ & $0.66 \pm 0.04^{\mathrm{b3}}$ & 4.30 & $0.70 \pm 0.02$ & 7.89 \\
$400 \mathrm{mg} / \mathrm{kg}$ & $0.50 \pm 0.02^{\mathrm{a} 2 \mathrm{~b} 2}$ & 27.60 & $0.57 \pm 0.06^{\mathrm{a} 2}$ & 25.00 \\
Loperamide 3 mg/kg & $0.38 \pm 0.02^{\mathrm{a} 3}$ & 45.00 & $0.41 \pm 0.02^{\mathrm{a} 3}$ & 46.00 \\
\hline
\end{tabular}

Data are expressed as mean $\pm \operatorname{SEM}(n=6) .{ }^{\mathrm{a} C o m p a r e d ~ t o ~ n e g a t i v e ~ c o n t r o l . ~}{ }^{\mathrm{b}}$ Compared to loperamide $3 \mathrm{mg} / \mathrm{kg} .{ }^{1} P<0.05,{ }^{2} P<0.01$, and ${ }^{3} P<0.001$. Negative controls received $10 \mathrm{ml} / \mathrm{kg}$ distilled water.

TABle 4: In vivo antidiarrheal index of crude extract of $H$. abyssinica.

\begin{tabular}{lccc}
\hline Dose administered & Delay in defecation time (Dfreq) (\%) & Gut meal travel distance (Gmeq) (\%) $\begin{array}{c}\text { Purging frequency in number } \begin{array}{c}\text { In vivo } \\
\text { of wet stools (\%) }\end{array} \\
\text { ADI }\end{array}$ & - \\
Control & - & - & - \\
$100 \mathrm{mg} / \mathrm{kg}$ & 74.62 & 14.87 & 42.85 \\
$200 \mathrm{mg} / \mathrm{kg}$ & 126.20 & 29.20 & 55.71 \\
$400 \mathrm{mg} / \mathrm{kg}$ & 134.46 & 54.00 & 73.85 \\
Loperamide 3 mg/kg & 189.45 & 67.10 & 59.00 \\
\hline
\end{tabular}

$\mathrm{ADI}=$ antidiarrheal index.

antidiarrheal agent. In the acute oral toxicity study, the crude extract of $H$. abyssinica at a single dose of $2 \mathrm{~g} / \mathrm{kg}$ body weight orally did not cause any major toxicity and death. This result displayed that the $\mathrm{LD}_{50}$ of $H$. abyssinica extract is greater than $2 \mathrm{~g} / \mathrm{kg}$. Thus, this finding supports the study which presents the tough evidence of the nontoxic outcome of the medicinal plant [29].

The crude extract of $H$. abysinica exhibited a dosedependent antidiarrheal activity in all diarrheal parameters such as the total number of stools, weight of wet stools, onset of diarrhea, and number of wet stools when compared with the negative control group. This finding is consistent with previous similar studies $[9,14,30]$. Medicinal plants with antidiarrheal activity are known to delay the onset of diarrhea and decrease the consistency of fecal droppings and the number of wet stools as reported for Saussurea lappa [31], Urena lobata [32], Lithocarpus dealbata, and Pterocarpus erinaceus [33].

In the current study, a castor oil-induced diarrheal model was conducted to evaluate whether the crude extracts of $H$. abyssinica have an antidiarrheal effect or not. Then, other in vivo models such as antientropooling and antipropulsive were done in an attempt to suggest other possible mechanisms of action like antisecretory activity and decrease 
in GI transit activities by which they displayed antidiarrheal effect. In the enteropooling model, the higher dose $(400 \mathrm{mg}$ / $\mathrm{kg}$ ) of the extract has a comparable antidiarrheal effect with loperamide $3 \mathrm{mg} / \mathrm{kg}$. However, the lower dose $(100 \mathrm{mg} / \mathrm{kg})$ lacks a noticeable antidiarrheal effect which could be attributed to the inability of the phytoconstituents to reach sufficient concentration to achieve antisecretory effect and decrease in GI transit effects [34].

Castor oil was used in the induction of diarrhea through inflammatory and irritation activities on GI mucosa via ricinoleic acid. Lipases are responsible for the release of ricinoleic acid from castor oil [35]. Ricinoleic acid is known to produce different effects in the GIT such as inflammation of the gut, local irritation, and release of prostaglandin leading to fluid hypersecretion and intestinal hyperactivity that ultimately rises GI peristalsis, reduction in the activity of $\mathrm{Na} / \mathrm{K}$-ATPase in the intestine, and finally end up with diarrhea $[36,37]$. Ricinoleic acid also forms salts with $\mathrm{K}^{+}$and $\mathrm{Na}^{+}$that will raise the permeability of the intestinal epithelium and constrain $\mathrm{Na} / \mathrm{K}$-ATPase, which in turn causes a cytotoxic consequence on intestinal cells [6]. Thus, the use of castor oil for the induction of diarrhea is sensible as it impressionists the pathophysiologic processes of motility and secretory diarrhea. In the present study, loperamide $3 \mathrm{mg} / \mathrm{kg}$ was used as the reference drug as it stimulates the absorption of glucose, electrolytes, and fluid through inhibition of prostaglandin activity [38].

In the castor oil-induced diarrheal model, the crude extract $H$. abyssinica revealed a significant reduction of the number of diarrheal episodes along with noticeable prolongation of the onset of the first diarrheal episode dosedependently. This indicates that a relatively high dose of the crude extract is required to produce a significant antidiarrheal activity. This finding is in agreement with previous similar studies $[9,39]$. The insignificant antidiarrheal effect of the crude extracts at the lower dose $(100 \mathrm{mg} / \mathrm{kg})$ could be because of the inability of the phytoconstituents to reach sufficient concentration to produce antidiarrheal effect. The crude extract of $H$. abysinica produces antidiarrheal activity that may be accredited to, at least in part, its antimotility effect.

The crude extract reduced GI peristalsis in castor oiltreated mice as exhibited by a reduction in GI movement of the charcoal meal transit at the higher doses $(400 \mathrm{mg} / \mathrm{kg})$ of $H$. abyssinica crude extract. The reduction in GI peristalsis endorses intestinal electrolyte and water absorption. Similar results were reported with Justicia schimperiana antimotility effect for antidiarrheal activity [14].

The other likely mechanism of $H$. abyssinica for its antidiarrheal effect might be through antisecretory activity as it was apparent from the reduction in the total number of wet feces due to the attendance of phytoconstituents such as anthraquinones, phenols, tannins, terpenoids, saponins, glycosides, flavonoids, and alkaloids [8]; quercetin 3-O$\beta$-glucoside, quercetin 3-O- $\beta$-glucuronide, quercetin glucuronide, and rutin [40]; protokosin, kosotoxin, $\alpha$-kosin, kosidin, $\beta$-kosin, bitter acrid resin, tannic acid, and volatile oil $[41,42]$; amino acids such as threonine, serine, aspartic acid, proline, glutamic acid, glycocol, valine, arginine alanine, methionine, cystine, leucine, tyrosine, iso-leucine, histidine, and phenylalanine [43]; minerals such as chromium, calcium, zinc, and other trace minerals [44]; and organic acids such as $\alpha$-ketoglutaric acid, malic acid, fumaric acid, citric acid, glycolic acid, and succinic acid were identified [43]. The existence of tannates in medicinal plants produces effects like reduction in secretion and makes the GI mucosa more resistant $[45,46]$. Tannins induce muscle relaxation through stimulation of the calcium pumping system or reduction of the intracellular $\mathrm{Ca}^{2+}$ inward current [47]. Tannins also denature proteins in the GI mucosa making protein tannates that make the GI mucosa more resistant and later decrease peristaltic movement. Tannins and tannic acid are water-soluble polyphenols that exist in many medicinal plants with antidiarrheal effects [48]. Flavonoids and tannins also rise the reabsorption of water and electrolytes by delaying castor oil-mediated NO production [39]. Diterpenes, sesquiterpenes, terpenes, terpenoids, and flavonoids are identified for hindering the release of prostaglandins and autacoids, thereby averting secretion and peristalsis induced by castor oil [49-51]. Steroids such as phytosterols and terpenoids such as abietic acid have been revealed to constrain the synthesis of prostaglandin E2, which are known to stimulate GI secretions [52, 53].

Moreover, the crude extract of $H$. abyssinica has shown anti-inflammatory activity like that of nonsteroidal antiinflammatory drugs [54]. Nonsteroidal anti-inflammatory drugs could hinder ricinoleic acid-induced diarrhea apart from its inhibition on prostaglandin synthesis via their antiinflammatory action [55]. Thus, it is rational to presume that the antidiarrheal effect of the crude extract of $H$. abyssinica could be accredited to anti-inflammatory effect. Most frequently used antidiarrheal medications act through averting the secretion of GI contents and/or reducing the GI peristalsis [25]. To evaluate the activity of medicinal plants on the GI peristalsis, an activated charcoal test is a chosen method [48, 56]. Activated charcoal was used in the GI motility test to serve as a marker. In the current study, the higher dose $(400 \mathrm{mg} / \mathrm{kg})$ of the crude extract repressed the charcoal marker which is similar to the reference drug (loperamide $3 \mathrm{mg} / \mathrm{kg}$ ). This finding displayed that the crude extract possesses an antimotility effect which is followed by more absorption of water and electrolytes. This might be responsible for the reduction in the number of wet and total feces.

\section{Conclusion}

The crude extract of $H$. abyssinica showed antidiarrheal activity via inhibition of secretion and antimotility activity. Thus, the antidiarrheal effect of the leaves of $H$. abysinica extract confirmed the traditional claim that the leaves of the plant are used for the treatment of diarrhea.

\section{Data Availability}

The datasets used and/or analyzed during the current study are available from the corresponding author upon reasonable request. 


\section{Ethical Approval}

Ethical clearance was obtained from the Research and Ethics Committee, Department of Pharmacology, University of Gondar, to conduct the study in an animal model with the reference number SOP 04-105-11.

\section{Conflicts of Interest}

The authors declare that they have no conflicts of interest.

\section{Authors' Contributions}

ZDK conceived the research, took the initiative of this work, and drafted the manuscript. ZDK, BBK, TYT, TFB, and SAA contributed to extraction, conducted each experiment, analyzed the data, organized relevant data, and revised the manuscript. Approval of the final manuscript was carried out by all authors.

\section{Acknowledgments}

The authors would like to acknowledge University of Gondar.

\section{References}

[1] M. D. Kirk, F. J. Angulo, A. H. Havelaar, and R. E. Black, "Diarrhoeal disease in children due to contaminated food," Bulletin of the World Health Organization, vol. 95, no. 3, pp. 233-234, 2017.

[2] E. T. R. McQuade, F. Shaheen, F. Kabir et al., "Epidemiology of Shigella infections and diarrhea in the first two years of life using culture-independent diagnostics in 8 low-resource settings," PLoS Neglected Tropical Diseases, vol. 14, no. 8, Article ID e0008536, 2020.

[3] C. L. F. Walker, I. Rudan, L. Liu et al., "Global burden of childhood pneumonia and diarrhoea," The Lancet, vol. 381, no. 9875, pp. 1405-1416, 2013.

[4] P. J. Pasricha, "Treatment of Disorders of Bowel Motility and Water Flux; Antiemetics; Agents Used in Biliary and Pancreatic Disease," Goodman and Gilman's the pharmacological basis of therapeutics, pp. 983-1019, McGraw-Hill Companies, Inc., New York, NY, USA, 2006.

[5] World Health Organization, Obesity: Preventing and Managing the Global Epidemic, World Health Organization, Geneva, Switzerland, 2000.

[6] K. S. Komal and A. Rana, "Herbal approaches for diarrhoea: a review," International Research Journal of Pharmacy, vol. 4, no. 1, pp. 31-38, 2013.

[7] Z. S. Kifle and Y. M. Belayneh, "Antidiabetic and antihyperlipidemic effects of the crude hydromethanol extract of Hagenia abyssinica (Rosaceae) leaves in streptozotocin-induced diabetic mice," Diabetes, Metabolic Syndrome and Obesity: Targets and Therapy, vol. 13, pp. 4085-4094, 2020.

[8] Z. D. Kifle et al., "Evaluation of in vivo antidiarrheal activity of solvent fractions of Hagenia abyssinica (Rosaceae) in Swiss albino mice," Evidence-Based Complementary and Alternative Medicine, vol. 2021, Article ID 8828331, 9 pages, 2021.

[9] D. Zayede, T. Mulaw, and W. Kahaliw, "Antidiarrheal activity of hydromethanolic root extract and solvent fractions of Clutia abyssinica Jaub. and Spach.(Euphorbiaceae) in mice,"
Evidence-Based Complementary and Alternative Medicine, vol. 2020, Article ID 5416749, 9 pages, 2020.

[10] Y. Maniyar, P. Bhixavatimath, and N. Agashikar, "Antidiarrheal activity of flowers of Ixora Coccinea Linn. In rats," Journal of Ayurveda and Integrative Medicine, vol. 1, no. 4, p. 287, 2010.

[11] A. A. Ahmadu, A. U. Zezi, and A. H. Yaro, "Anti-diarrheal activity of the leaf extracts of Daniellia oliveri Hutch and Dalz (Fabaceae) and Ficus sycomorus Miq (Moraceae)," African Journal of Traditional, Complementary, and Alternative Medicines: AJTCAM, vol. 4, no. 4, pp. 524-528, 2007.

[12] A. Degu et al., "Evaluation of the antidiarrheal activity of hydromethanol crude extracts of Ruta chalepensis and Vernonia amygdalina in mice," Evidence-Based Complementary and Alternative Medicine, vol. 2020, Article ID 8318713, 6 pages, 2020.

[13] M. Sisay, E. Engidawork, and W. Shibeshi, "Evaluation of the antidiarrheal activity of the leaf extracts of Myrtus communis Linn (Myrtaceae) in mice model," BMC Complementary and Alternative Medicine, vol. 17, no. 1, pp. 1-11, 2017.

[14] B. Mekonnen, A. B. Asrie, and Z. B. Wubneh, "Antidiarrheal activity of $80 \%$ methanolic leaf extract of Justicia schimperiana," Evidence-Based Complementary and Alternative Medicine, vol. 2018, Article ID 3037120, 10 pages, 2018.

[15] T. Feyissa, Micropropagation, Transformation and Genetic Diversity of Hagenia Abyssinica (Bruce) JF Gmel, Swedish University of Agricultural Sciences, 2006.

[16] H. Beentje, J. Adamson, and D. Bhanderi, Kenya Trees, Shrubs, and Lianas, National Museums of Kenya, 1994.

[17] B. Assefa, G. Glatzel, and C. Buchmann, "Measuring soil fertility underHagenia abyssinica(bruce) J. F. Gmel by the biotest method," International Journal of Agronomy, vol. 2010, no. 1 , pp. $1-5,2010$.

[18] A. Enyew, Z. Asfaw, E. Kelbessa, and R. Nagappan, "Ethnobotanical study of traditional medicinal plants in and around Fiche District, Central Ethiopia," Current Research Journal of Biological Sciences, vol. 6, no. 4, pp. 154-167, 2014.

[19] L. C. Ngeny, E. Magiri, C. Mutai, N. Mwikwabe, and C. Bii, "Antimicrobial properties and toxicity of Hagenia abyssinica (bruce) JF gmel, fuerstia africana TCE fries, Asparagus racemosus (willd.) and ekebergia capensis sparrm," African Journal of Pharmacology and Therapeutics, vol. 2, no. 3, 2013.

[20] G. Bekele and P. R. Reddy, "Folklore medicinal uses of Hagenia abyssinica (Bruce) JF Gmel to treat human ailments by Guji Oromo tribes in Abaya district, Borana Zone, Oromia regional state Ethiopia," International Journal of Physical and Social Sciences, vol. 4, no. 12, p. 394, 2014.

[21] T. Wolde, B. Bizuayehu, T. Hailemariam, and K. Tiruha, "Phytochemical analysis and Antimicrobial activity of HAGENIA ABYSSINICA," Indian Journal of Pharmacy and Pharmacology, vol. 3, no. 3, pp. 127-134, 2016.

[22] S. D. Sarker, Z. Latif, and I. Alexander, Gray Natural Products Isolation, Human Press Inc, NJ, USA, 2006.

[23] B. Geleta et al., "In vivo antihypertensive and antihyperlipidemic effects of the crude extracts and fractions of Moringa stenopetala (Baker f.) Cufod. leaves in rats," Frontiers in Pharmacology, vol. 7, p. 97, 2016.

[24] O. T. No, "425: acute oral toxicity: up-and-down procedure," OECD Guidelines for the Testing of Chemicals, Section, vol. 4, pp. 1-27, 2008.

[25] M. Molla, N. Gemeda, and S. M. Abay, "Investigating potential modes of actions of Mimusops kummel fruit extract and solvent fractions for their antidiarrheal activities in mice," 
Evidence-Based Complementary and Alternative Medicine, vol. 2017, Article ID 4103410, 11 pages, 2017.

[26] M. M. Suleiman, B. B. Oyelowo, A. Abubakar, M. Mamman, and K.-d. T. Bello, "A controlled study to investigate antidiarrhoeal effect of the stem-bark fractions of Terminalia avicennioides in laboratory animal models," International Journal of Veterinary Science and Medicine, vol. 5, no. 1, pp. 14-22, 2017.

[27] Z. Hussain, G. Amresh, S. Singh, and C. V. Rao, "Antidiarrheal and antiulcer activity ofAmaranthus spinosusin experimental animals," Pharmaceutical Biology, vol. 47, no. 10, pp. 932-939, 2009.

[28] E. E. Oghenesuvwe et al., "Preclinical screening techniques for anti-diarrheal drugs: a comprehensive review," AMERICAN JOURNAL OF PHYSIOLOGY, vol. 7, no. 2, pp. 61-74, 2018.

[29] W. H. Organization, The Guidebook to the Registration of Public Health Pesticides and Repellents against Vectors: Hazard Classification-Acute LD50 Values of Formulated Products, 2019.

[30] A. B. Asrie, M. Abdelwuhab, Z. Shewamene, D. A. Gelayee, G. M. Adinew, and E. Birru, "Antidiarrheal activity of methanolic extract of the root bark of Cordia africana," Journal of Experimental Pharmacology, vol. 8, pp. 53-59, 2016.

[31] S. Negi et al., "Antidiarrheal activity of methanol extract and major essential oil contents of Saussurea lappa Clarke," African Journal of Pharmacy and Pharmacology, vol. 7, no. 8, pp. 474-477, 2013.

[32] A. K. Yadav and V. Tangpu, "Antidiarrheal activity ofLithocarpus dealbata. and Urena lobata. Extracts: therapeutic implications," Pharmaceutical Biology, vol. 45, no. 3, pp. 223-229, 2007.

[33] I. M. Ezeja, I. I. Ezeigbo, K. G. Madubuike et al., "Antidiarrheal activity of Pterocarpus erinaceus methanol leaf extract in experimentally-induced diarrhea," Asian Pacific Journal of Tropical Medicine, vol. 5, no. 2, pp. 147-150, 2012.

[34] W. C. Evans, Trease and Evans' Pharmacognosy E-Book, Elsevier Health Sciences, 2009.

[35] S. Tunaru, T. F. Althoff, R. M. Nusing, M. Diener, and S. Offermanns, "Castor oil induces laxation and uterus contraction via ricinoleic acid activating prostaglandin EP3 receptors," Proceedings of the National Academy of Sciences, vol. 109, no. 23, pp. 9179-9184, 2012.

[36] E. W. Horton, I. H. Main, C. J. Thompson, and P. M. Wright, "Effect of orally administered prostaglandin E1 on gastric secretion and gastrointestinal motility in man," Gut, vol. 9, no. 6, pp. 655-658, 1968.

[37] A. Robert, J. E. Nezamis, C. Lancaster, A. J. Hanchar, and M. S. Klepper, "Enteropooling assay: a test for diarrhea produced by prostaglandins," Prostaglandins, vol. 11, no. 5, pp. 809-828, 1976.

[38] F. Ching et al., "Antidiarrhoeal activities of aqueous extract of Stereospermum kunthianum (Cham, Sandrine Petit) stem bark in rodents," African Journal of Biotechnology, vol. 7, no. 9, 2008.

[39] J. Galvez, A. Zarzuelo, M. E. Crespo et al., "Antidiarrhoeic activity of Sclerocarya birrea bark extract and its active tannin constituent in rats," Phytotherapy Research, vol. 5, no. 6, pp. 276-278, 1991.

[40] H. Thomsen et al., "Characterization of constituents and anthelmintic properties of Hagenia abyssinica," Scientia Pharmaceutica, vol. 80, no. 2, pp. 433-446, 2012.

[41] K. B. M. Taha, Study of the Major Flavonoids from Balanites Aegyptiaca, Cissus Petiolata and Hegeina Abyssinica, Sudan University of Science and Technology, 2015.
[42] E. Nibret and M. Wink, "Trypanocidal and antileukaemic effects of the essential oils of Hagenia abyssinica, Leonotis ocymifolia, Moringa stenopetala, and their main individual constituents," Phytomedicine, vol. 17, no. 12, pp. 911-920, 2010.

[43] P. C. M. Jansen, Spices, Condiments and Medicinal Plants in Ethiopia, Their Taxonomy and Agricultural Significance, Pudoc, 1981.

[44] M. Amde, N. Megersa, A. M. Taddesse, and T. Bedassa, "Determination of the levels of selected metals in seeds, flowers and fruits of medicinal plants used for tapeworm treatment in Ethiopia," Toxicological and Environmental Chemistry, vol. 95, no. 1, pp. 82-100, 2013.

[45] K. Tripathi, Essentials of medical pharmacology, vol. 5, pp. 235-249, Jaypee Brothers. Medical publishers (P) LTD, New Delhi, India, 2003.

[46] S. Das, R. Prakash, and S. N. Devaraj, “Antidiarrhoeal effects of methanolic root extract of Hemidesmus Indicus (Indian Sarsaparilla) - an in vitro and in vivo study," Indian Journal of Experimental Biology, vol. 41, pp. 363-366, 2003.

[47] T. E. Odike, Antidiarrhoeal Effect of Unripe Musa Paradisiacae Pulp and Peel Homogenates on Castor Oil-Induced Diarrhoea in Wistar Albino Rats, 2017.

[48] M. F. Tagne et al., "Activity of Oxalis barrelieri aqueous extract on rat secretory diarrhea and intestine transit," Journal of Applied Pharmaceutical Science, vol. 5, no. 1, pp. 58-62, 2015.

[49] V. F. Veiga Jr, L. Zunino, J. o. B. Calixto, M. L. Patitucci, and n. C. Pinto, "Phytochemical and antioedematogenic studies of commercial copaiba oils available in Brazil," Phytotherapy Research, vol. 15, no. 6, pp. 476-480, 2001.

[50] R. Milanova, K. Han, and M. Moore, "Oxidation and glucose conjugation of synthetic abietane diterpenes by Cunninghamella sp. II. Novel routes to the family of diterpenes from Tripterygium wilfordii," Journal of Natural Products, vol. 58, no. 1, pp. 68-73, 1995.

[51] J. B. Nikiéma, R. Vanhaelen-Fastré, M. Vanhaelen, J. Fontaine, C. De Graef, and M. Heenen, "Effects of antiinflammatory triterpenes isolated fromLeptadenia hastatalatex on Keratinocyte Proliferation," Phytotherapy Research, vol. 15, no. 2, pp. 131-134, 2001.

[52] A. B. Awad, J. Toczek, and C. S. Fink, "Phytosterols decrease prostaglandin release in cultured P388D1/MAB macrophages," Prostaglandins, Leukotrienes and Essential Fatty Acids, vol. 70, no. 6, pp. 511-520, 2004.

[53] M. J. Bern, C. W. Sturbaum, S. S. Karayalcin, H. M. Berschneider, J. T. Wachsman, and D. W. Powell, "Immune system control of rat and rabbit colonic electrolyte transport. Role of prostaglandins and enteric nervous system," Journal of Clinical Investigation, vol. 83 , no. 6 , pp. 1810-1820, 1989.

[54] T. F. Belachew, S. Asrade, M. Geta, and E. Fentahun, "In vivo evaluation of wound healing and anti-inflammatory activity of $80 \%$ methanol crude flower extract of Hagenia abyssinica (Bruce) JF Gmel in mice," Evidence-Based Complementary and Alternative Medicine, vol. 2020, Article ID 9645792, 12 pages, 2020.

[55] F. Awouters, C. J Niemegeers, F. M Lenaerts, and P. A Janssen, "Delay of castor oil diarrhoea in rats: a new way to evaluate inhibitors of prostaglandin biosynthesis," The Journal of Pharmacy and Pharmacology, vol. 30, no. 1, pp. 41-45, 1978.

[56] Z. Hunegnaw, D. A. Gelayee, and Z. S. Sabe, "In vivo antidiarrheal activity evaluation of the seeds of Sorghum bicolor L.(Poaceae)," Discovery Phytomedicine, vol. 3, no. 4, p. 22, 2016. 